3. Кондратюк А. 3 вишневого саду: наук.-худож. оповідання / А. Кондратюк ; передм. В. Скуратівського. - К. : Молодь, 1991. - 192 с.

4. Кононенко В. І. Рідне слово / В. І. Кононенко. К. : Богдана, 2001. - 305 с.

5. Лозко Г. П. Етнологія України: філософсько-теоретичний та етнорелігієзнавчий аспект / Г. П. Лозко. К. : АртЕк, 2004. - С. 304.

6. Михасюк Т. В. Мовленнєвий розвиток молодших школярів у процесі позакласної народознавчої роботи : дис. ... канд. пед. наук : 13.00.02 / Михасюк Тетяна Володимирівна ; Рівненський держ. гуманіт. ун-т. - Рівне, 2012. $283 \mathrm{c}$.

7. Науменко В. Художній твір як мистецтво слова / В. Науменко // Учитель початкової школи. - 2014. № 4. - C. 9 .

УДК 37.091.4:37.091.33-028.17

DOI: 10.37026/2520-6427-2020-101-1-114-117
8. Плис О. В. Формування образного мислення у молодших школярів / О. В. Плис // Початкове навчання та виховання. - 2014. - № 31/32. - С. 5.

9. Потапенко О. І. Шкільний словник з українознавства / О. І. Потапенко, В. І. Кузьменко. - К. : Український письменник, 1995. - С. 227.

10. Потебня О. О. Естетика і поетика слова / О. О. Потебня ; упор. І. В. Іваньо. - К. : Мистецтво, 1985. - C. 182.

11. Смолінська О. С. Лінгводидактичні основи національно-мовного виховання особистості засобами українського фольклору : дис. ... канд. пед. наук : 13.00.02 / Смолінська Олеся Свгеніївна ; АПН України, Інститут педагогіки. - К., 1999. - С. 136.

12. Сухомлинський В. О. Вибрані твори : в 5 т. / В. О. Сухомлинський. - К., 1977. - Т. 3. - С. 176-177.

Дата надходження до редакиї: 23.12.2019 p.

Володимир ОМЕЛЬЧУК,

кандидат педагогічних наук, доиент Дубенського коледжу

Рівненського державного гуманітарного університету

Наталія МАРТОЛОГ,

науковий кореспондент

лабораторії вікової психофізіології

Інституту психологіi

імені Г. С. Костюка НАПН Украӥни,

директор ТОВ «Центр розвитку дитини

«Дитяча країна»»,

смт Глеваха Київської області

\title{
ПРОБЛЕМА ВЗАЕМОВІДНОСИН ТА СПІЛКУВАННЯ В ПЕДАГОГІЧНІЙ СПАДЩИНІ ВАСИЛЯ СУХОМЛИНСЬКОГО
}

У статті розглядається проблема взаємовідносин та спілкування як суттєвий чинник, щуо забезпечує розв'язання складних навчально-виховних завдань. Особлива увага акиентується на важливості використання педагогічної спадшини Василя Сухомлинського у виріменні означеної проблеми.

Ключові слова: міжособистісні взаємини, спілкування, педагогічний такт, професійне спілкування, толерантність, комунікативні здібності.

В статье рассматривается проблема взаимоотношений и общения как существенный фактор, обеспечиваюший решение сложных учебно-воспитательных задач. Особое внимание акцентируется на важности использования педагогического наследия Василия Сухомлинского в решении этой проблемьл.

Ключевые слова: межличностные отночения, общение, педагогический такт, профессиональное общение, толерантность, коммуникативные способности.
The practice of school life has shown that the success of the educational process is decisively determined by the relationship between teacher and students, student and his peers, teacher and parents, child and parents.

All children, regardless of their learning outcomes, need a tolerant treatment and high culture of communication. Children of the XXI century are children with high levels of emotional sensitivity, hyperactivity and expressiveness who are painfully responsive to any demonstration of injustice.

The problem of relationships and communication in student teams should be a priority issue in every educational institution.

Lack of tact and kindness is one of the causes of conflict between teacher and students. The lack of these qualities significantly reduces the possibilities of the educational process, as Vasyl Sukhomlynsky has repeatedly emphasized. Today, his ideas and expressions in the context of solving this problem deserve special status. 
The idea of love, humanity, humanism, tolerant attitude to the students is the cross-cutting theme of the whole Vasyl Sukhomlynsky's pedagogical heritage.

The teacher-educator urged teachers to avoid anger, rudeness, not to be "thick-skinned», because it negatively affects the atmosphere and the means of education and training.

Vasyl Sukhomlynsky considered a word as an important means of moral education of children and human language culture as a mirror of spiritual culture. V. Sukhomlynsky emphasized that one should be particularly tolerant to a slow learner.

In "School under the blue sky» V.Sukhomlynsky created such a collective in which the atmosphere of mutual respect and help prevailed. The outstanding teacher was well aware that it was the nature of the relationship in a team that determined the status of each child, his emotional and mental well-being.

Key words: interpersonal relationships of communication, pedagogical tact, professional communication, tolerance, communicative abilities.

Актуальність. Інстинкт агресії, насильства, взаємної нетерпимості, який сьогодні активізувався в українському суспільстві, викликає глибоке занепокоєння в представників науково-освітянської інтелігенції та батьківської громадськості. Політичні дискусії, які презентують 3МІ, пронизані зневагою, нетерпимістю опонентів один до одного. Атмосфера та риторика цих дискусій - агресивно-войовнича. Вона не сприяє утвердженню в суспільстві, особливо в молодіжному середовищі, правової культури та толерантності. Саме така модель взаємовідносин, яка базується на приниженні гідності людини, нав'язується суспільним інституціям, що забезпечують процес формування особистості.

Особливу тривогу сьогодні викликає модель взаємовідносин у загальноосвітній школі, в якій намагаються «отримати прописку» такі негативні психологічні явища, як булінг, цькування, інтелектуальна дискримінація тощо.

Практикою шкільного життя доведено, що успіхи освітнього процесу найбільшою мірою визначаються взаєминами між учителем і учнями, учнем і його ровесниками, учителем і батьками, дитиною і батьками.

Сьогодні все частіше вчителі скаржаться на те, що учні стали «важкими». Раніше працювати із дітьми було набагато легше. Сучасні діти інші: вони боляче реагують на фальш, несправедливість і безтактність учителя [1, с. 37].

Відомо, що нетактовність учителя щодо зовнішнього вигляду, розуму, здібностей, висловлена в грубій формі та ще й у присутності ровесників, боляче вражає підлітків. Такі зауваження можуть часом назавжди відштовхнути учня від учителя.

Зважаючи на те, що рівень престижності професії педагога стрімко знижується, кількість «випадкових» учителів із низькою загальною культурою та незадоволених своїм матеріальним статусом, відповідно, збільшується, проблема формування комунікативних здібностей майбутнього вчителя набуває в експертному освітянському середовищі особливої актуальності.

Без відродження соціального престижу вчительської професії, не посилюючи при цьому психологічної культури майбутнього педагога, школа перетвориться в середовище приниження, розчарування, невдоволення, фрустрації та депресії.
Уже десятки років український учитель, як ніхто інший, відчуває на собі суспільну несправедливість та дискримінацію. Чи під силу такому педагогу розв'язання складних освітніх завдань, створення атмосфери творчості, взаємної поваги та толерантності? Уміння взаємодіяти з учнями в процесі розв'язання освітніх завдань, виявляти до них високий рівень культури спілкування, створювати на уроці емоційний комфорт - це неабияке мистецтво, яке не під силу кожному.

Усі діти, незалежно від результатів їхньої навчальної діяльності, потребують толерантного ставлення та високої культури спілкування. Діти XXI ст. - це діти з високим рівнем емоційної чутливості, гіперактивності та експресивності, які боляче реагують на будь-які прояви несправедливості. Раннє «спілкування» 3 мобільними телефонами, комп'ютерами, безтактність батьків та вчителів - головні причини дитячої агресії та злочинності. За останніми даними статистики, дитяча злочинність зростає неймовірними темпами. Хто іiі стимулює? Очевидно, що ми - батьки, вчителі, які втрачають авторитет в очах школярів. Подвійні стандарти, фальш, яку презентують дорослі, є однією із причин неадекватної поведінки школярів. Легковажне ставлення до означеної проблеми має свою ціну: підірване психічне здоров'я дитини, покалічені дитячі душі, втрата сенсу життя... Зважаючи на це, проблема взаємовідносин та спілкування в учнівських колективах повинна стати пріоритетною для обговорення в кожній освітній установі. Будь-які прояви дискримінаційного ставлення з боку вчителя щодо розумових здібностей дитини слід вважати підставою для його звільнення з посади та притягнення до адміністративної відповідальності.

Варто також зауважити, що наявність у школах дошок пошани, а як наслідок - публічний порівняльний аналіз результатів навчальної діяльності школярів $€$ ознакою їхньої розумової дискримінації. Публічне визнання успішних учнів негативно відображається на психоемоційному стані іншої категорії школярів. Такі засоби стимулювання не сприяють утвердженню в учнівських колективах атмосфери взаємної поваги, толерантності, терпимості та комфортного емоційного середовища. При цьому ми відчуваємо емоційний стан школярів, особливо батьків, діти яких з огляду на свої можливості ніколи не стануть відмінниками чи спортсменами школи.

Глава УГКЦ, Блаженніший Святослав, звертаючись до учнів, зауважив: «У школі дуже важливо вчитися і отримувати хороші оцінки. Але найважливіше - навчитися бути людиною. Уміти розрізняти між тим, що є добре, і тим, що є погане. Поганого завжди уникати, а те, що є добре, - уміти робити. Робити для тих, хто поруч: рідних, близьких. Бо лише тоді, коли чините добре, ви стаєте добрими людьми».

Безперечно, українська школа пишається своїми відмінниками, переможцями олімпіад, спортсменами... А ті, хто має добре серце, з повагою відносяться до батьків, людей поважного віку, своїх ровесників хіба не гордість школи? Невже ми не розуміємо, що відмінні оцінки - це не показник людяності школяра, а лише рівень його інтелекту? На жаль, здебільшого на практиці українське учительство сприймає дитину через призму його результатів навчальної діяльності.

3 огляду на негативні явища, які сьогодні мають місце в освітньому середовищі, проблема взаємовідносин та спілкування в педагогічній спадщині Василя Сухомлинського - мудрого педагога та великого вчителя - набуває особливої актуальності. 
Мета статті - висвітлити основні проблеми міжособистісних взаємин та спілкування в педагогічній спадщині Василя Сухомлинського з погляду сьогодення; визначити шляхи, які сприятимуть формуванню комунікативної культури українського вчителя.

Зважаючи на мету, основними завданнями роботи є:

1) розкрити роль і місце взаємовідносин та спілкування в розв'язанні освітніх завдань;

2) проаналізувати шляхи формування комунікативної культури вчителя в контексті педагогічних ідей і порад Василя Сухомлинського.

Аналіз наукових досліджень та публікацій. Означена проблема для психолого-педагогічної науки не нова. Вона була та є предметом дослідження значної кількості вітчизняних та зарубіжних філософів, педагогів та психологів, зокрема неабияку увагу їй приділяли такі вчені, як В. Войтко, Д. Карнегі, Є. Головаха, Н. Паніна, Г. Сагач, Б. Ломов, Н. Петровський, Я. Коломенський, Г. Товканець, Л. Савенкова, Т. Ковбасюк, В. Омельчук, К. Шорохова, С. Соловейчик, I. Синиця, I. Зязюн, М. Опольська, І. Горєлов, Н. Бабич, А. Грохольська та ін.

Варті уваги також думки та поради Конфуція, Сократа, Платона, які розглядали найбільш характерні якості людини, що роблять іiі приємною та корисною в суспільстві [2, с. 14]. Водночас теоретико-практичну цінність мають дослідження А. Савенкової та Г. Товканець. Зокрема, Г. Товканець зазначає, що рівень культури мовлення вчителів недостатній, що відповідно знижує й ефективність їх професійної діяльності [5, с. 50].

Виклад основного матеріалу. Брак такту і доброти - одна із головних причин конфліктних ситуацій між учителями й учнями. Дефіцит цих якостей суттєво зменшує можливості освітнього процесу, що неодноразово зауважував Василь Сухомлинський. Сьогодні його ідеї та поради в контексті вирішення означеної проблеми варті особливої уваги. Зокрема, ідея любові, людяності, гуманізму, толерантного ставлення до учнів червоною ниткою проходить через усю педагогічну спадщину науковця. Його філософсько-психологічні поради, переконання, роздуми - ключ до професійного успіху кожного вчителя, небайдужого до долі дитини.

Ким для Василя Сухомлинського є дитина, особистість? Насамперед дитина - це найвища цінність, а особистість - індивідуум із почуттям власної гідності. Бажання вчитися дуже легко зупинити різкістю, грубістю та байдужістю. При цьому дітей з обмеженими здібностями необхідно розвивати, аби дитина відчувала своє зростання, переживала радість успіху. Педагог повинен бути чуйним, сердечним та тактовним. Таким чином у дитині повинно утверджуватися прагнення бути хорошою і не бути поганою. Адже людина звелася над світом усього живого насамперед тому, що горе інших стало її особистим горем. Тому робити добро потрібно не тільки тоді, коли тебе бачать люди - значно більше треба для того, щоб бути справжньою людиною, коли тебе ніхто не бачить. Дати дітям радість праці, радість успіху в навчанні, пробудити в їхніх серцях почуття гордості, власної гідності - це ключова заповідь виховання.

Виховання дітей 6-10 років В. Сухомлинський називав «школою сердечності» та радив педагогам i батькам вчити дітей добру, любові, милосердю.
Дитина не повинна виростати байдужою, черствою, вона має зростати в постійному піклуванні про навколишній світ рослин, тварин, людей, доглядати і допомагати їм.

Професія вчителя передбачає величезну відповідальність. Подібно лікарю, який неточним рухом ножа може позбавити людину життя, учитель необережним словом може завдати маленькій дитині непоправної шкоди: «Слова - це найтонший інструмент, за допомогою якого ми доторкаємося до серця дитини; вони можуть стати ніжною, запашною квіточкою, живою водою, що навертає віру в добро, або ж гострим ножем, розпеченим залізом і брудом». Тому користуйтеся словом вміло та пам'ятайте про його могутню силу. I нехай слова 3 ваших уст ніколи не будуть литися брудом, а стануть благодатним вогнем, що нестиме у світ лише красу та радість [3, с. 31].

Видатний учений-педагог закликав учителів уникати озлобленості, грубості, не бути «товстошкірими», адже це негативно відображається на атмосфері та засобах навчання і виховання. У книзі «Серце віддаю дітям» він наголошував: «Найголовніше для вчителя - насамперед бачити дитяче горе, сум, страждання. Бачити і відчувати дитячу душу. В тому, як учитель ставиться до горя дитини, наскільки здатний він розуміти й відчувати дитячу душу, полягає основа його педагогічної майстерності» [3, с. 35].

Гуманність неможлива без чуйності до людини. Як зазначає Василь Олександрович, кожен із нас повинен бути не лише прекрасним умільцем, майстром, творцем матеріальних цінностей, а й душевною, чутливою людиною. Водночас ніколи не втратять свого значення слова В. Бєлінського: «Будемо теслярами, будемо слюсарями, будемо фабрикантами; але чи будемо людьми - ось питання!» [3, с. 35].

Важливим засобом морального виховання дітей Василь Олександрович вважав слово, а мовну культуру людини - дзеркалом духовної культури. Слово - не лише носій інформації, зазначав дослідник, воно - іскра, від якої розгорається полум'я інтересу, вікно в незвідане, тому має бути яскравим, образним, барвистим і точним. Слово в руках учителя - найтонший і найголовніший його інструмент. Він неодноразово наголошував, що багато шкільних конфліктів, які нерідко закінчуються великою бідою, починаються насамперед із невміння вчителя спілкуватися з учнями. Підтримуючи думку щодо високої мовної культури кожного педагога, Василь Олександрович зазначав, що вихователь має вибирати з мовної скарбниці саме ті слова, що відкривають шлях до людського серця неповторного, несхожого на інші. А для того, щоб виховувати словами, необхідно передусім розвивати сприйнятливість до слова.

Видатний педагог радить учителям розвивати, поглиблювати у своїх колективах педагогічну етику, утверджувати гуманне начало у вихованні як найважливішу рису педагогічної культури кожного вчителя.

Непорушним педагогічним переконанням Василя Сухомлинського була істина: чуйність і лагідність - це та духовна сила, яка здатна зберегти дитяче серце від огрубіння, озлоблення, жорстокості та байдужості, від безсердечного ставлення до всього доброго і світлого в житті, теплого слова. Зло в дитячому серці породжується тільки грубістю та байдужістю дорослих.

Учитель повинен бути для дитини такою ж дорогою людиною, як і мати. Віра школяра в учителя, 
взаємна довіра між ними, людяність і доброта - ось те, що необхідно вихователю, те, що хочуть бачити діти у своєму наставнику. Одна 3 найцінніших його якостей - людяність, в якій поєднується серцева доброта 3 мудрою суворістю батьків.

Видатний педагог був переконаний, що немає жодної дитини нездібної, бездарної: «У природі немає дитини безталанної, ні на що не здатної. Кожному можна дати щастя творення, кожного треба вивести в люди». Кожен школяр розвивається власними своєрідними шляхами, кожен розумний і талановитий по-своєму. Гуманізм у педагогіці він вбачав у тому, щоб дитина, якій не під силу те, що легко дається більшості, не почувалася неповноцінною. При цьому Василь Олександрович наголошував, що слід проявляти особливу терпимість до учня, який «відстає». Недовіра, підозрілість, упередженість в оцінці віддаляють його від вихователя та обмежують можливості виховного впливу на нього.

Як ніхто інший, В. Сухомлинський бачив неабияку виховну небезпеку в тому, що освіта орієнтується на інтелектуальний розвиток школяра, не приділяючи при цьому належної уваги людському серцю, не розгортаючи систематичної рефлексивної діяльності в означеному напрямі. Сутність процесу виховання підростаючої особистості він вбачав у культивуванні сердечності.

У «Школі під блакитним небом», створеній самим педагогом, В. Сухомлинський сформував навколо себе такий колектив, в якому панувала атмосфера взаємної поваги і допомоги. Він чудово розумів, що саме від особливостей взаємовідносин у колективі залежить статус кожної дитини, ii емоційне і розумове благополуччя. При цьому характер взаємовідносин у класному колективі значною мірою залежить від культури спілкування, адже спілкування - це шлях до взаєморозуміння, духовного та інтелектуального самозбагачення. Якою стане людина, залежить від того, як вона спілкується з іншими людьми, до чого вона прагне та який світ людського багатства відкривається перед нею.

На думку педагога, учитель виховає справжній колектив юних громадян лише тоді, коли йому пощастить досягти тієї мети, щоб спілкування зі своїм колективом для кожної особистості стало радістю, розкішшю; коли діти нестимуть у колектив власні роздуми, сумніви, тривоги; коли вихованці збиратимуться просто заради того, щоб поговорити про все, що кого хвилює.

Упродовж останніх років своєї діяльності Сухомлинський рішуче відстоював думку, що виховання учнів несумісне з покаранням. Він мав на увазі грубе відчитування, висміювання, виставлення 3 класу, залишення винного після уроків для виконання будьякої роботи, записування скарг у щоденник: «Лихо багатьох учителів у тім, що вони вимірюють та оцінюють духовний світ дитини тільки оцінками і балами, поділяють усіх учнів на дві категорії залежно від того, чи вчать, чи не вчать діти уроки» [3, с. 123].

Сухомлинський рекомендував педагогам викликати у школу батьків не з приводу поганої успішності або дисципліни їхньої дитини, а тоді, коли вона робить щось хороше, нехай незначний на перший погляд, але добрий вчинок. У їх присутності дитину важливо похвалити, підтримати та неодмінно зробити відповідний запис у щоденнику.
Така система виховання, в основу якої покладено оцінку лише позитивних результатів, надзвичайно рідко призводить до психічних зривів, до появи «важких» підлітків. Василь Олександрович постійно наголошував, що справедлива похвала, заохочення учня, колективу - це велика виховна сила, яка сприяє зростанню почуття власної гідності заохочуваних, у них виникає бажання працювати ще краще. Проте, на його думку, не слід заохочувати «кращих серед гірших». Це стосується як окремого учня, так і колективу загалом.

Серед основних причин покарань учнів у школі В. Сухомлинський виокремлював такі, як низька педагогічна культура; недосконала організація освітнього процесу; відсутність єдності вимог керівництва школи, вчителів і батьків; невміння деяких педагогів правильно використовувати систему оцінювання; невідповідність покарань здійсненим учинкам учнів тощо. У зв'язку з цим науковець застерігав від несправедливих покарань, які надривають духовне та фізичне здоров'я дітей і призводять до неврозів.

Австралійський учений А. Коккеріль свого часу на прохання Ольги Сухомлинської так прокоментував увагу західних учених до ідей Василя Олександровича: «3 огляду на реалії західного способу життя - увагу до інтелекту, економічний раціоналізм, прагнення до прибутку - ми не виховуємо душу, серце і внаслідок цього маємо багато різних проблем. Гуманітарні науки перебувають у кризовому стані, родини розпадаються... Зазвичай дідусі й бабусі живуть окремо від молодих сімей, що негативно впливає на виховання дітей; катастрофічно знижується рівень масової культури; люди втрачають віру один в одного. За такої ситуації спадщина В. Сухомлинського набуває величезної ваги». Справді, його праці є нагадуванням про призначення людини на землі, їі потенціал [4].

Висновок. Завдання сучасної української школи не обмежується створенням умов для інтелектуального зростання школярів. Сьогодні українська школа має передусім стати осередком добра, сердечності, толерантності, центром духовно-морального зростання кожної дитини. Ми повинні пишатися всіма учнями, та особливо тими, які виявляють велику любов і турботу до батьків, бабусь, дідусів, повагу до людей похилого віку, вчителів та своїх однокласників. Такі діти завжди будуть справжньою гордістю не лише для сім’ї, школи, а й усієї держави загалом.

\section{СПИСОК ВИКОРИСТАНОЇ ЛІТЕРАТУРИ}

1. Войтко В. І. Психологічна наука, вчитель, учень / В. Войтко. - Київ, 1979. - С. 37.

2. Ковбасюк Т. Міжособистісні взаємини і спілкування як соціально-гуманітарна проблема сьогодення / Т. Ковбасюк, В. Омельчук // Нова педагогічна думка. - 2012. - № 1. - С. 14.

3. Омельчук В. В. Педагогіка Василя Сухомлинського - педагогіка гуманізму / В. В. Омельчук // Матеріали регіональної науково-практичної конференції «Реформування сучасної освіти: діалог із В. Сухомлинським». - Рівне : РОІППО, 2018.

4. Ткаченко Л. Василь Сухомлинський: світове визнання / Л. Ткаченко // Директор школи. - 2003. № 33 (273), вересень.

5. Товканець Г. Культура професійного спілкування / Г. Товканець // Початкова школа. - 1997. № $10 .-$ C. 50 .

Дата надходження до редакиї: 21.01.2020 р. 